\title{
DERECHO PENAL
}




\title{
PROFANACIÓN, EXHUMACIÓN Y VIOLACIÓN DE LOS ENTERRAMIENTOS: ARQUEOLOGÍA PENAL DE SU REGULACIÓN EN EL SIGLO XIX
}

\author{
Dr. David Castro Liñares \\ Universidad de Alicante \\ david.castro@ua.es
}

\begin{abstract}
Sumario: Introducción. 1. El tratamiento penal a los actos contra el cuerpo y la memoria de los difuntos en los Códigos Penales españoles decimonónicos (1822, 1848, 1850 y 1870). 2. Razones político-criminales subyacentes a la tipificación penal de las conductas indebidas para con los difuntos. 2.1 La influencia de la religión frente al inveterado trauma de lo mortuorio. 2.2. La Economía Política de la Pena como marco de referencia para el análisis de la delincuencia patrimonial fúnebre. 2.3 Higienismo y Medicina Social como reguladores de un nuevo orden urbano 3. Recapitulación conclusiva. 4. Bibliografía.
\end{abstract}

Resumen: Este trabajo tiene como finalidad analizar el tratamiento penal que durante el siglo XIX se dispensó a los actos indebidos para con el cuerpo y memoria de las personas fallecidas. Para ello, este texto se inicia con un recorrido normativo por los Códigos Penales españoles del siglo XIX (1822-1848-1850-1870) con el propósito de analizar la forma en que el Legislador penal fue incorporando esta cuestión en los distintos textos normativos. A continuación, y como forma de continuar este análisis, se estima adecuado detenerse en las razones político criminales subyacentes a la tipificación de estas conductas. De esta forma, se intenta realizar una aproximación a las lógicas punitivas decimonónicas inherentes a una esfera tan particular como el castigo penal a los actos irrespetuosos para con los difuntos. Por último, se incorpora un apartado conclusivo en el que abordar algunas ideas que, por razón de estructura narrativa no encontraban un acomodo idóneo en otras partes del texto pero que igualmente resultan de importancia para esta propuesta de análisis político-criminal histórico.

Palabras Clave: Derecho Penal, Siglo XIX, Profanación, Religión, Economía Política de la Pena, Salud Pública. 


\begin{abstract}
This work aims to analyse the criminal law treatment that during the 19th century is dispensed to wrongdoing with the body and memory of deceased people. For that purpose, this text begins with a normative view of the Spanish Criminal Codes of the 19th century (18221848-1850-1870) in order to investigate how the Criminal Legislator incorporated this issue into the various normative texts. Hereunder, as a way to continue this analysis, it is considered appropriate to dwell on the criminal political reasons typification of these conducts. In this way, an attempt is made to approximate the decimonic punitive logics inherent in an area as particular as criminal punishment to disrespectful acts with the deceased. Finally, a concluding section is incorporated in order to address some ideas that, by reasons of narrative structure, did not find an appropriate accommodation in other parts of the text but which are also relevant for this proposal of historical political-criminal analysis.
\end{abstract}

Keywords: Criminal Law, XIXth Century, Desecration, Religion, Political Economy of Punishment, Public Health.

\title{
Introducción
}

El estudio histórico de la Ciencias Penales encuentra en el siglo XIX un fecundo lugar de trabajo. Esto es así en la medida en que durante este período se produce en Europa Occidental y sus zonas de influencia un asentamiento hegemónico del proceso de codificació ${ }^{1}$. En este sentido, el estudio de los distintos Códigos Penales (CP) vigentes en aquella época permite escrutar la influencia que múltiples lógicas punitivas poseían en la configuración del escenario jurídico penal. Asumido este punto de partida como referencia, a través de este trabajo se intenta realizar una aproximación, principalmente político-criminal, a la configuración penal de los actos indebidos para con los difuntos como hechos merecedores de castigo penal.

Para ello, en primer lugar se realiza un sucinto recorrido por los diferentes CP españoles del XIX que permita acercarse a la regulación específica sobre la materia. Esta labor permite, aunque sólo sea por razón de su presentación secuencial, comparar los distintos tipos dedicados a esta materia y establecer sus similitudes y diferencias. En segundo lugar, se propone un recorrido político-criminal que permita estudiar algunas de las razones que posiblemente resultaron de importancia para el Legislador penal a la hora de configurar estos delitos. En tercer y último lugar, se esbozan algunas ideas sobre la procedencia y necesidad de estudiar tipos penales históricos, así como también se pergeñan algunos apuntes sobre la importancia de estas contribuciones en trabajos sobre delitos actuales.

1 Sobre el proceso de codificación penal en España, sin ánimo de exhaustividad, véase por todos MASFERrer DOMINGo (2017). 


\section{EI tratamiento penal a los actos contra el cuerpo y la memoria de los difuntos en los Códigos Penales españoles decimonónicos $(1822,1848,1850$ y 1870)}

La realización de un sucinto ejercicio de revisión histórica como el que se pretende en este apartado permite poner de manifiesto cómo la tipificación de las conductas irrespetuosas para con el cuerpo y la memoria de los fallecidos ha sido una preocupación político-criminal constante a lo largo de todo los Códigos penales del siglo XIX: 1822, 1848, 1850, y 1870².

Sentado lo anterior, y de una manera más específica, el Código Penal de 1822 tipifica como delito la violación de los enterramientos en el artículo 682 con el siguiente tenor literal:

Artículo 682 CP de 1822. "El que a sabiendas abra o quebrante sepulcro o sepultura, bien para aprovecharse de sus materiales, bien para despojar al cadáver alli sepultado de sus vestiduras o efectos, bien para desenterrar sus restos, o deshonrarlos de cualquier otro modo, sufrirá un arresto de tres meses a un año, y pagará una multa de cinco a treinta duros; sin perjuicio de ser castigado como ladrón con violencia a las personas si robare alguna cosa. Exceptúese el caso de exhumación por orden de una autoridad legítima, y el de la apertura que pasado el tiempo competente hagan los encargados de los cementerios públicos, conforme a los reglamentos o prácticas que rijan».

Este delito se ubica en el Capítulo IV «Rapto fuerzas y violencias contras las personas y violaciones de los enterramientos» presente en el Título I «De los delitos contra las personas» perteneciente a la Parte II del Código Penal «De los delitos contra los particulares». Tal como se acaba de referir, el artículo 682 CP 1822 comparte Capítulo con tipos penales cuyo contenido de injusto recae, necesariamente, sobre cuerpos vivos. De esta intitulación se puede inferir que para el Legislador penal de 1822 los restos mortales eran algo más que simple materia inerte ${ }^{3}$. Así pues, y

2 López Barja De Quiroga, Rodríguez Ramos Y Ruiz De Gordejuela lópez (1988), 1385. Dicho esto, es preciso apuntar que la represión de los actos indebidos para con los difuntos no es una preocupación surgida ex novo, puesto que es posible encontrar referencias específicas a esta cuestión en textos normativos anteriores y de carácter internacional (In extenso, Groizard Y Gomez De La Serna (1870) 6-10, 14-21). Es más, El debido respeto a un difunto y su memoria se encuentra en el centro de una preocupación que ha acompañado a culturas y sociedades desde tiempos inmemoriales (LAQUEUR (2015)). De hecho, la intranquilidad generada por la realización de actos que pudieran resultar desconsiderados para con el cuerpo de una persona fallecida era apreciable ya en la época romana y suscitaba una preocupación que se explicitaba en las inscripciones realizadas en lápidas y enterramientos (Del Hoyo (2014); LAFuenTE BenAches (2016), 3536). Esta misma autora señala casos excepcionales en los que la no inhumación podría ser contemplada por razones crudelia creditoris o de cumplimiento de un castigo (LAFUENTE BENACHES (2016), 36).

3 Pacheco (1870), 43. 
en la medida en que se ubican al lado de los delitos contra las personas, se puede pensar que para el Legislador el cadáver todavía es depositario de la dignidad humana inherente a las personas vivas y por tanto los atentados que pueda sufrir deben ser merecedores de reproche penal ${ }^{4}$. De hecho, así de tajante se mostraba PACHECO a la hora exponer el agravio que suponía mantener posturas transigentes frente a estos actos: "Si hubiese sociedad alguna que abandonase al capricho, a la irreligión, a la mofa de cualquiera los huesos de sus difuntos; si hubiese hijos que no garantizáran de tales desacatos a las tumbas de sus padres; esa sociedad seria indigna de permanecer sore la faz de la tierra: esos hijos merecerían la maldición de los espíritus que reposan en el seno de la eternidad ${ }^{5}$ ».

Todo lo recién expuesto puede resultar llamativo por lo inesperado que resulta desde la perspectiva actual que el art. $682 \mathrm{CP} 1822$ fuese un ilícito contra las personas y no un delito contra la religión católica. Esta última ubicación puede parecer, a priori, más adecuada por dos razones. En primer lugar, todo aquello que atañe a la muerte, o en este caso a su perturbación, se tendía a pensar en aquel entonces como actos con fuertes posos religiosos. En segundo lugar, resulta extraño que dada la influencia de la religión católica en España a principios del Siglo XIX ${ }^{6}$, el Legislador penal fuese capaz de desarrollar un marco jurídico que no tuviese en cuenta esto.

No obstante, todo lo anterior debe ser puesto en cuestión para evitar caer en juicios que puedan deslizarse hacia posturas excesivamente presentistas $^{7}$. Para ello, es preciso volver a la última idea expuesta en el párrafo anterior. En este sentido, la religión católica se encuentra tan entreverada en el contexto en el que se gesta y promulga el CP de 1822 que su ascendencia sobre la vida, pública y privada, de la ciudadanía resultaba totalmente incuestionable ${ }^{8}$. Todo esto condiciona la visión del Legislador hasta el punto de que algo tan consesualmente asumido como la influencia en el comportamiento colectivo de los dogmas católicos no tiene por qué ser explicitado $^{9}$. En consecuencia, el Legislador de 1822 no explica la vinculación de la violación de los enterramientos con los delitos contra la religión, porque las implicaciones religiosas de estos delitos se daban por asumidas.

Con posterioridad a este primer ejercicio codificador surgen, años después, los Códigos Penales de 1848 y 1850. En ellos la violación de los enterramientos, al igual que en el código predecesor, también se recoge como un ilícito autónomo con el siguiente tenor literal (idéntico en ambos CP):

\footnotetext{
4 Sobre la concepción de persona en Derecho Penal, Ramos Vázouez (2014).

PACHeCo (1870), 43.

6 Cuello Calón, (1954), 923 y ss.; Manjón-Cabeza Olmeda (2013); Vilá Mayo (1983), 1066.

7 Sobre el concepto de presentismo, y sin ánimo de exhaustividad, dada la amplitud del concepto, Moro Abadia (2006).

8 Manjón-Cabeza Olmeda (2013); Terradillos Basoco (2010).

9 En relación con esta última idea, PAcheco (1870), 43.
} 
Artículo 138 CP 1848-1850: "El que exhumare cadáveres humanos, los mutilare o profanare de cualquier otra manera, será castigado con la pena de prisión correccional».

Una vez expuesto el tipo, es importante señalar que el Legislador penal de 1848 y 1850 realiza un cambio de gran importancia en la rúbrica de estos delitos. En estos CP los actos indebidos para con los difuntos se ubican dentro del Título I «Delitos contra la Religión» del Libro Segundo «Delitos y sus penas». Este cambio de ubicación implica modificaciones sustanciales en su tenor literal. En los CP de 1848 y 1850 el Legislador utiliza terminología de naturaleza más técnica y próxima a la empleada en las disciplinas médico-legales ${ }^{10}$. Así pues, en el art. 138 se pueden encontrar los verbos exhumar, mutilar o profanar como formas de describir la conducta típica. La introducción de verbos con significados tan claros como estos revierte en la construcción de un tipo aparentemente más aséptico que su precedesor, en el que se encontraban referencias al vocablo deshonrar como verbo rector de los actos llevados a cabo contra los restos mortales de una persona.

En todo caso, lo que parece claro es que el viraje operado por el Legislador penal evidencia un cambio respecto de la situación iniciada con el CP de $1822^{11}$. De hecho, lo recién expuesto marca la existencia de toda una serie de modificaciones que tan sólo se entienden de forma completa si se cohonestan con la nueva rúbrica de estos tipos dentro de los delitos contra la religión. Dicho esto, y con el fin de contextualizar un poco más los cambios producidos en los CP de 1848 y 1850, el Legislador penal de mediados del siglo XIX consideró necesario explicitar la religiosidad subyacente a estos delitos puesto que, a su juicio, ya no resultaba evidente que el respeto a los difuntos tuviese un sustrato esencialmente religioso ${ }^{12}$. Así las cosas, y para evitar lecturas seglares, reforzó su naturaleza religiosa en lo que podría entenderse como un exceso provocado por una suerte de efecto de sobrecompensanción. De esta forma, el Legislador penal a través de esta manifestación de religiosidad explícita intenta despejar las posibles dudas que puedan surgir sobre la mirada que se debe de tener a la hora proteger los actos indebidos para con los difuntos ${ }^{13}$.

Todo lo anterior parece cambiar con la aprobación del Código Penal de 1870. El contexto socio-político abierto por razón de la Revolución Gloriosa de 1868 produce un influjo liberal que facilita la incorporación de un amplio elenco de derechos y libertades individuales otrora vetados

10 De Castro Y Orozco Y Ortiz De Zuñiga (1848), 16.

11 Sobre el incipiente debate sobre la procedencia de tratar penalmente cuestiones que atañen al decoro y la moral religiosa, in extenso, PACHECo (1870), 52 y ss.

12 Tamarit Sumalla (1989), 99.

13 Pacheco (1870), 44-45, 53 y ss.; Vizmanos Y Álvarez Martínez (1848), 36. 
en Códigos Penales anteriores ${ }^{14}$. Todo esto propicia que el último Legislador penal del siglo XIX vuelve a modificar la ubicación de estos ilícitos desdoblando el castigo penal de los actos indebidos para con los difuntos en dos delitos autónomos recogidos en los artículos 349 y 350 CP 1870 .

Articulo 349 CP 1870: "El que practicare o hubiere hecho practicar una inhumación, contraviniendo a lo dispuesto por las leyes o los reglamentos respecto al tiempo, sitio o demás formalidades prescritas para las inhumaciones, incurrirá en las penas de arresto mayor y multa de 150 a 1500 pesetas».

Artículo 350 CP 1870: «El que violare los sepulcros o sepulturas, practicando cualesquiera actos que tiendan directamente a faltar al respeto a la memoria de los muertos, será condenado con las penas de arresto mayor y multa de 125 a 1250 pesetas».

Resulta importante destacar que estos delitos tienen la consideración de Capítulo propio. Así, los arts. 349 y 350 del CP 1870 conforman el Capítulo I "Infracción de leyes sobre inhumaciones y la violación de los sepulcros» perteneciente al Título V "de la infracción de leyes sobre inhumaciones y la violación de los sepulcros y delitos contra la Salud Pública» del Libro II «De los Delitos y sus penas». Sin embargo, la presencia en este CP de esta materia no resulta completa de obviarse la existencia de una falta específica (artículo 596.6) ubicada en el Título II «De las faltas contra los intereses generales y régimen de las poblaciones» del Libro III "De las faltas y sus penas».

Artículo 596 CP de 1870: «Serán castigados con la pena de multa de 5 a 25 pesetas y reprensión:

$6^{\circ}$ Los que profanaren los cadáveres, cementerios o lugares de enterramiento, por hechos o actos que no constituyan delito».

De la lectura de estos artículos se puede apreciar que el Legislador de 1870 consolida la técnica legislativa mostrada por su predecesor en los CP de 1848 y 1850. Así pues, no sólo mantiene un lenguaje de carácter técnico, sino que también se preocupa por reforzar el correcto proceder en materia exhumatoria ${ }^{15}$.

El establecimiento de una suerte de policía mortuoria refuerza la preocupación por la vertiente técnica de estas prácticas y centra sus objetivos en castigar acciones de las que se pueden derivar graves consecuencias de naturaleza colectiva ${ }^{16}$. En este sentido, la intitulación de

14 Entre otros, Catalá (2018), 24-25; Colomer Bea (2019), 11-12; Souto Galván (2016), 336; TAMARit Sumalla (1989), 100.

15 Groizard Y Gomez De La Serna (1870), 10. Sobre el proceder administrativo en materia inhumatoria, in extenso, LAFUENTE BENACHES (2016).

16 Groizard Y Gomez De La Serna (1870), 10-11. 
estos delitos resulta perfectamente coherente con el establecimiento de un nuevo capítulo dedicado a los delitos contra la salud pública. En este sentido, y como forma de ejemplificar la mayor importancia de la vertiente sanitaria de estos delitos, parece adecuado mostrar cómo en el CP de 1870 se prevén penas más graves para las inhumaciones ilegales (art. 349 CP 1870) que para los actos indebidos para con los difuntos y su memoria artículo (art. 350 CP 1870).

Esta línea de análisis permite rastrear la existencia de una evolución en la racionalidad punitiva que coincide con una tendencia a la secularización de la respuesta penal frente a estos delitos ${ }^{17}$. Esto es así en la medida en que se desplazan las razones de carácter moral y religioso a un espacio secundario y se pone el foco de atención sobre aspectos de salud pública indispensables para la supervivencia y el bienestar colectivo ${ }^{18}$. De todos modos, y a pesar de que el factor religioso pierde centralidad en la configuración jurídico-penal, esto no debe entenderse, de ningún modo, como una preterición de su influencia político-criminal ${ }^{19}$. Así las cosas, el Estado siguió protegiendo a la Iglesia católica y su concepción moral de la vida pública y privada ${ }^{20}$.

En suma, y a título de recapitulación para todo lo expuesto en este apartado, es posible sostener que para el Legislador penal del siglo XIX los delitos contra los actos indebidos para con los difuntos no resultaban una materia cómoda de abordar. De otro modo difícilmente se puede explicar que hayan sufrido modificaciones de ubicación y contenido en todos los Código Penales decimonónicos (a excepción de los de 1848 y 1850) ${ }^{21}$. En este sentido, parece clara la existencia de intensas divergencias entre los postulados que defendidos a nivel teórico y la forma de llevarlos a la práctica. Dicho de otro modo, es posible constatar un sólido consenso sobre la necesidad de castigar los actos atentatorios para con los difuntos y su memoria. No obstante, esto no evitó la proliferación de un intenso debate sobre cómo plasmar esa voluntad punitiva en los diferentes CP.

\section{Razones político-criminales subyacentes a la tipificación penal de las conductas indebidas para con los difuntos}

El periplo mostrado en el apartado anterior pone de manifiesto que el accidentado recorrido normativo que experimentaron estos delitos du-

\footnotetext{
17 Groizard Y Gomez De La Serna (1870), 24.

18 Groizard Y Gomez De La Serna (1870), 13.

19 Groizard Y Gomez De La Serna (1870), 25.

20 Catalá (2018), 45.

21 En este sentido, Lafuente Benaches (2016), 117-118.
} 
rante el siglo XIX no puede considerarse una mera consecuencia del azar. Todos estos cambios legislativos pueden ser interpretados como testigos de la existencia de un complejo contexto socio-político que, sin lugar a dudas, condiciona el contenido y alcance de los delitos contra los actos indebidos para con los difuntos.

Por ello, y con la intención de clarificar un poco esta cuestión, este apartado se detiene en algunas de las razones/influencias que el Legislador penal posiblemente pudo manejar a la hora de configurar estos delitos. De una manera más específica, este apartado se centra en tres ideas: 1. La influencia político-social de la religión católica; 2 . La voluntad represiva de la pobreza en general y de la delincuencia patrimonial en particular; 3. La preocupación por la gestión del medio urbano y el intento de vehicular una solución a través del higienismo y la medicina social.

\subsection{La influencia de la religión frente al inveterado trauma de lo mortuorio}

La muerte ha conformado, desde siempre, una preocupación central para la Humanidad ${ }^{22}$. La complejidad inherente a este concepto permite recordar que, al menos desde un punto de vista antropológico, «la idea de la muerte propiamente dicha es una idea sin contenido, o, si se quiere, cuyo contenido es el vacío del infinito. Es la más vaga de las ideas vacías, pues, su contenido no es sino lo impensable, lo inexplorable, el «no sé qué» conceptual que corresponde al «no sé qué» cadavérico. La idea de la muerte es la idea traumática por excelencia ${ }^{23}$,. Este traumatismo, narrado a veces en términos de horror ${ }^{24}$, implica tener que gestionar, tanto en solitario como colectivamente ${ }^{25}$, premisas tan tajantes como la finitud de la vida o la pérdida de la individualidad que se deriva del fallecimiento ${ }^{26}$.

En relación con esto, la religión emerge como un elemento fundamental a través del que acercarse a la comprensión y gestión de todo lo que rodea al fallecimiento de una persona. Por ello, muerte y religión se encuentran indisociablemente unidas desde los albores de la Humani$\operatorname{dad}^{27}$. De hecho, la religión tiene en el estudio, compresión y gestión de la muerte uno de sus tópicos fundamentales ${ }^{28}$. Sentado lo anterior, y de una manera más concreta, es posible sostener que una de las funciones principales de la religión reside en intentar paliar los traumatismos que

\footnotetext{
22 MORIN (1994), 21 y ss.

23 MORIN (1974), 32.

24 Hertz (1990), 88.

25 Hertz (1990), 90.

26 MORIN (1974), 30-31.

27 Hertz (1990), 19 y ss.; Morin (1974), 21 y ss.

28 Basterra PÉREZ (2006), 203-243.
} 
genera la defunción. De esta forma, la religión se puede concebir como "el suspiro de la criatura oprimida, el sentimiento de un mundo sin corazón, así como el espíritu de una situación carente de espíritu ${ }^{29}{ }^{\prime}$, es decir, una forma de vehicular y, en cierto modo, de dotar de sentido a las pasiones tristes generadas por la muerte.

Sin embargo, la función de la religión no se detiene ahí, ya que desarrolla una posición proactiva que ofrece alternativas frente a los inexorables efectos de la muerte. Así pues, en esta faceta de «mediación», otorga a las sociedades patrones de comportamiento, comprensión y actuación con los que construir respuestas, individuales y colectivas, frente al fallecimiento $^{30}$. En este sentido, la religión, sirve como elemento de arbitraje en el tránsito de la vida a la muerte. Por ello, y para poder gestionar el inestable equilibrio en el que se ubica, incorpora elementos provenientes tanto del ámbito de lo racional como lo irracional, ya que, «solo desde esa paradójica posición entre lo racional y lo irracional se puede superar el sinsentido del individuo frente a la muerte ${ }^{31 » .}$

Más allá de estas consideraciones generales, es preciso detenerse en algunas de las interpretaciones que desde el catolicismo se realizan sobre la muerte en general, y sobre el cadáver en particular ${ }^{32}$. Todo ello permite acercarse, al menos en parte, a las ideas que justificaban la tipificación de los actos indebidos contra las personas fallecidas. Antes de continuar, es preciso apuntar que un estudio de la muerte desde el prisma del catolicismo implica una profundidad y extensión analítica que excede, con mucho, los objetivos de este trabajo. Así pues, la vocación en la que se encuadra este apartado reside en intentar mapear algunas de las implicaciones que para del catolicismo tienen el cuerpo y la muerte. Todo ello con la vocación de enmarcar estos análisis dentro de las razones que el Legislador decimonónico tomó para la tipificación de los delitos contra los actos indebidos para con el cuerpo y memoria de los difuntos.

De acuerdo con la tradición de las primeras comunidades cristianas, el cuerpo posee un lugar protagónico en tanto que receptáculo del Espíritu Santo y por tanto santuario y templo vivo de Dios ${ }^{33}$. Así pues, y en línea con una interpretación próxima a la que se puede extraer de los textos bíblicos, se estima que "Jesús, utilizando la riqueza semiótica de la corporalidad, construye múltiples analogías orientadas a revindicar la vida espiritual del hombre. Reelabora un reencantamiento y sacralización de la materia física, proponiendo que es el cuerpo físico, el lugar natural de

29 MARX (1974), 94.

30 Morin (1974), 83.

31 BASTERra PÉREZ (2006), 211.

32 Sobre la interpretación que desde el cristianismo se puede realizar de alguna cuestión relacionada con la muerte, ABEL (1983).

33 Viviani (2007), 25. 
morada de la dimensión espiritual del hombre ${ }^{34} »$. En este mismo sentido, y desde una doble perspectiva (cristológica y mística/idealista), autores como Joseph RATZINGER sostienen que la presencia divina no se puede entender separada de la entidad corporal de cada persona ${ }^{35}$. De hecho, esta forma de entender la espiritualidad, que fue mayoritaria en los primeros cristianos, negaba la necesidad de construir templos físicos, ya que cada creyente, per se, estaba habitado por la divinidad y por lo tanto no tenía que acudir a un espacio ad hoc para ejercer su fe $\mathrm{f}^{36}$.

En conexión con lo anterior, lo recién expuesto permite conectar con otro tema de gran importancia para el cristianismo, la relación cuerpo/ alma, y cómo esta se vincula con los conceptos de encarnación y resurrección ${ }^{37}$. En relación con esta cuestión, y descendiendo a un plano más específico, es importante traer a colación la interpretación que Pablo de Tarso realiza sobre esta cuestión y que presenta en su primera carta a los Corintios (1 Corintios 6, 12-20). En este texto, Pablo de Tarso teoriza sobre la existencia de una dualidad cuerpo físico/espiritual, si bien no llega a establecer una diferencia clara entre estos dos conceptos ${ }^{38}$. En todo caso, los postulados paulinos se ubicaron durante mucho tiempo en el centro del debate sobre la resurrección escatológica ${ }^{39}$, cuestión primordial para la antropología y ética cristianas ${ }^{40}$, y si bien no se cuestiona su gran importancia teológica, esta teoría en la actualidad es considerada, por algunos sectores doctrinales, como una interpretación insuficiente o superada ${ }^{41}$.

De todos modos, la doctrina paulina se trae a colación aquí no sólo por su valor teológico, sino también por su importancia política ${ }^{42}$. Los textos de Pablo de Tarso pueden ser leídos en clave política en la medida en que de sus propuestas se colige un nuevo orden social ${ }^{43}$. Pablo construye gran parte de sus argumentos con base en la asunción de que la

34 ViVIANi (2007), 26.

35 RATZINGER (2007), 76-77.

ViVANI (2007), 21-24.

7 NADEAu (2005), 155 y ss.

NADEAU (2005), 156-157.

Libanio (1983); RATZINGER (2016); SolANo (2014).

O'CALlaghan (1989), 777.

41 Libanio (1983), 580; Nadeau (2005), 155 y ss.; O’CAllaghan (1989), 799 y ss. El planteamiento de esta cuestión no se puede desligar de la contextualización de la figura de su promotor, Pablo de Tarso. Así pues, su origen semita juega un papel de suma importancia en la medida en que sus teorizaciones sobre la materialidad/inmaterialidad del cuerpo no se pueden comprender despegadas de su origen. LIBANIO (1983), 580-582; O'CALLAGHAN (1989), 778 y ss.

42 Zamora (2010), TAubes (2007).

43 En este punto, es necesario resaltar de nuevo el origen judío de Pablo de Tarso, pues esto tiene una influencia muy notable en la construcción de sus postulados teológicos, Llamas Velas, (2009); Piñero Sáez (2014); Segovia (2013). 
segunda venida de Jesucristo es inminente ${ }^{44}$. En consecuencia, y desde el mesianismo ${ }^{45}$ inherente a este planteamiento, construye un nuevo horizonte de los posibles incompatible con el statu quo vigente ${ }^{46}$. Esto es así en la medida en que «el tiempo mesiánico nos conduce a una nueva experiencia del tiempo que no puede ser comprendida en términos del tiempo cronológico, sino que es un tiempo presente que interrumpe aquí y ahora el tiempo profano. No es el fin del tiempo sino el tiempo del final ${ }^{47}{ }^{\prime}$. Esta concepción de la realidad resulta fundamental para entender el alcance de las implicaciones políticas de los argumentos paulinos. De hecho, para autores como BADIOU ${ }^{48}$, los textos de Pablo de Tarso marcan el acontecimiento fundacional a partir del cual fijar la construcción de una subjetivación netamente cristiana. En relación con esta cuestión, ZI$\mathrm{ZEK}^{49}$ va incluso un poco más allá, y atribuye a Pablo una labor fundamental en el proceso de institucionalización del Cristianismo ${ }^{50}$. Así pues, y en línea con lo anterior, es posible sostener que al formular todas estas cuestiones teológicas, Pablo de Tarso está sentando las premisas de un relato identitario extensible a todos aquellos individuos que abrazasen la fe cristiana. Esta identidad, construida a la contra, otorga al resto de la población (los no judíos) un gran potencial político, puesto que los reconoce como sujetos políticos preexistentes por derecho propio ${ }^{51}$. En este sentido, y sobre la base de estas nociones, es posible construir una rudimentaria acepción de pueblo en la que «no es ni el todo ni la parte, ni mayoría ni minoría. El pueblo es más bien lo que no puede jamás coincidir consigo mismo, ni como todo ni cómo parte ${ }^{52}$ ». Así las cosas, los argumentos anteriores permiten interpretar la teología paulina como

44 Agamben (2006), 91 y ss.

45 Sobre una lectura de esta cuestión en clave de teología política, GALINDo HeRvás (2008), ZAMORA (2010).

46 Taubes (2010), 92 y ss.

47 Zamora (2010), 96. In extenso, Agamben (2006) 67 y ss.

48 BADIOU (1999), 15.

49 ZIZEK (2005), 18-20.

50 A mayor abundamiento, se considera oportuno traer a colación la argumentación de Zizek, quién se apoya los paralelismos entre Pablo de Tarso y Lenin, para sostener la idea de Pablo de Tarso como una personaje fundamental en la ritualización e institucionalización del cristianismo: "Después de establecer la muerte y resurrección de Jesús, Pablo continúa con su verdadero negocio leninista, el de organizar el nuevo partido llamado comunidad cristiana. Pablo considerado un leninista ¿Por qué no? ¿No fue Pablo, como Lenin, el gran "institucionalizador»y, como tal, no fue vilipendiado por los partidarios del cristianismo-marxismo "original»? La temporalidad del "ya pero no todavía» ¿no designaba también la situación intermedia de Lenin entre las dos revoluciones, entre febrero y octubre de 1917?». ZIZEK (2005), 18-19.

51 Agamben (2006), 72.

52 Agamben (2006), 72. En un sentido coincidente, si bien con base en otra terminología, Foucault sostenía que «la plebe probablemente no existe, pero la hay. Existe la plebe en los cuerpos, en las almas, en los individuos, en el proletariado, pero con extensión, forma, energía e irreductibilidad diversas en cada caso». Foucault (1994), 421. Sobre esta idea de plebe/pueblo, in extenso RANCIÈRE (1996). 
una forma de impulsar la creación de potentes sentimientos comunitarios sostenidos, en gran medida, sobre la base de una espiritualidad compartida. Todo este acervo cultural y comunitario de raíz cristiana se entreveró socialmente en el imaginario colectivo hasta conformar un sustrato cultural generador de una suerte de cosmovisión mortuoria que intentaba explicar las atávicas complejidades subyacentes al fallecimiento al tiempo que ritualizaba los procesos a través de los que transitar por estas situaciones. Por todo ello, las consideraciones religiosas son fundamentales a la hora de intentar comprender valores culturales como el tratamiento debido a un cadáver o la creencia en la inmaterialidad del alma.

Todo lo anterior permite sostener que la defunción es mucho más que el cese biológico de una vida. De hecho, analizar la muerte desde un punto de vista unívocamente orgánico imposibilita alcanzar una óptima delimitación conceptual de lo mortuorio. Así las cosas, la muerte, en tanto que concepto de innegable raigambre histórico-social, configura toda una serie de usos, ritos y conceptos que convergen entorno a la idea de que el cadáver y la memoria de una persona fallecida son elementos dignos de respeto.

Así las cosas, y en seguimiento de lo expuesto a lo largo de todo este apartado, se podrían inferir que la religión católica tuvo una influencia determinante en los derroteros por los que discurrió el legislador penal decimonónico ${ }^{53}$. En este sentido, ejerció como un constante motor político-criminal cuya presencia se manifestaba con mayor intensidad en aquellos tipos con mayor contenido ético/moral. Este era, precisamente, el caso de los delitos contra los actos indebidos para con los difuntos y su memoria. Estamos, por tanto, ante una categoría delictiva que se configura como tal precisamente por la consideración ético/moral que la sociedad le otorgaba a la realización de estos actos. De hecho, y más allá de los matices presentes en cada $\mathrm{CP}$, la interpretación común del bien jurídico protegido de estos delitos residía en la salvaguarda de la incolumidad de los sujetos ultrajados. En este sentido, existe una fuerte conexión entre ética, moral y religión a la hora de concebir la dañosidad social de estas conductas. Por todo ello, y ya a título de cierre, es preciso reiterar que no es posible pensar que la delimitación del contenido de injusto de estos delitos desoyendo la influencia que una eventual lectura católica pudiese realizar sobre contra los actos indebidos para con los difuntos y su memoria.

53 Sobre esta cuestión, sin ánimo de exhaustividad, ANTón ONECA (1965), 273; CuEllo Calón, (1954), 923 y ss.; Catalá (2018); García García, (1999); Groizard Y Gomez De La Serna (1870), 24 y ss.; Manjón-Cabeza Olmeda (2013); Pacheco (1870), 53 y ss.; Tamarit Sumalla (1989), 98-100; Terradillos Basoco, (2010): Vilá Mayo (1983), 1066; Vizmanos Y ÁlVAREZ MARTínez (1848), 36. 


\subsection{La Economía Política de la Pena como marco de referencia para el análisis de la delincuencia patrimonial fúnebre}

Las primeras formulaciones típicas que se realizaron en el siglo XIX de los delitos contra los actos indebidos para con los difuntos prestaban una especial atención a sus consecuencias patrimoniales. Este hecho merece una especial consideración, puesto que, de una manera intuitiva podría pensarse que estos actos no tendrían por qué considerarse como actos deshonrosos para con los difuntos. Así las cosas, esta relación no debería ser muy próxima, ya que las relaciones económicas no parecen estar muy correlacionadas con la memoria de las personas fallecidas. No obstante, si se acude a la primera codificación española de 1822, se puede apreciar como el Legislador prevé un castigo especial para todo tipo de disposiciones patrimoniales ilícitas/no autorizadas que se pudieren realizar sobre un cadáver. Dicho de otro modo, se castiga el hurto/robo a una persona fallecida. En definitiva, y dada la importancia atribuida a estas conductas, parece clara la existencia de una firme voluntad en la persecución de lo que podría denominarse como delincuencia patrimonial fúnebre.

Sentado lo anterior, es importante destacar que para poder comprender mejor el afán del legislador penal por castigar disposiciones patrimoniales realizadas sobre los difuntos, es necesario reparar en la existencia de un contexto mucho más amplio en el que los actos contra la propiedad privada y el fortalecimiento del incipiente orden económico-social capitalista suscitaba un gran interés para los poderes públicos ${ }^{54}$. Por ello, y como forma de abordar esta cuestión, se estima oportuno analizarla desde el marco analítico que ofrece la denominada economía política de la pena ${ }^{55}$. La economía política de la pena parte de la base de que el castigo estatal no se puede entender desligado de la estructura económica y el mercado de trabajo ${ }^{56}$. En este sentido, y dada la importancia que el Legislador otorgaba a la protección penal del patrimonio y la propiedad de los medios de producción, es posible que la economía política de la pena permita comprender mejor la relación que media entre la estructura económica europea de fines del siglo XVIII y la represión de todas aquellas conductas deshonrosas para con el cuerpo y la memoria de los difuntos.

En conexión con todo lo anterior, y como forma de sistematizar la información expuesta, es necesario fijar el punto de partida en la Baja Edad Media Europea. Esto es así en la medida en que este período se

54 Sin ánimo exhaustividad, Brandariz Garcia (2019); CASTEl (2009); Melossi Y PaVARINI (1980); Procacci (1991); RuSCHE Y KIRCHHEIMER (2004).

55 El concepto de economía política de la pena se encuentra inicialmente desarrollado en la obra Pena y Estructura Social de George Rusche y Otto Kirchheimer, (Rusche Y KIRCHHEIMER (2004)). Sobre este concepto in extenso, BRANDARIz GARCIA (2019), 19 y ss.; De Giorgi (2006); Garland (1990), 83 y ss.; Melossi, Sozzo Y Brandariz Garcia, (2018).

56 Brandariz Garcia (2019), 24; De Giorgi (2006), 6 y ss. 
puede constatar la existencia de una férrea voluntad de combatir todo tipo de delincuencia patrimonial ${ }^{57}$ así como de reprimir a todos aquellos sujetos susceptibles de entrar en esta categoría delincuencial ${ }^{58}$. De acuerdo con los usos medievales, la delincuencia patrimonial no conformaba una categoría delictiva nítidamente definida. El perfil de lo que comúnmente se conocía como ladrón poseía límites difusos que lo equiparaban a personas sin oficio, ocupación o vivienda conocida. Dicho de otro modo, los ladrones eran igualados y mezclados con todos aquellos sujetos a los que se conocía como vagos, mendigos o vagabundos ${ }^{59}$. Esta heterogénea amalgama de situaciones particulares era tratada con especial rigor y dureza ${ }^{60}$, ya que se consideraba que así era la única forma eficaz de reducir su propagación ${ }^{61}$. Esta confusión en torno al perfil y naturaleza de la delincuencia patrimonial, si bien actualizada, mantiene su vigencia en los albores del capitalismo pues los delincuentes patrimoniales, al igual que los mendigos o los vagos, seguían siendo percibidos como elementos indeseables para la sociedad ${ }^{62}$. Sentado lo anterior, la pobreza resulta un elemento común a todos los perfiles sociales recién descritos, lo que colabora en la formación de un poso conceptual con base en el que afirmar que la pobreza debe ser «elevada al nivel de peligro social ${ }^{63}{ }$. Esto es así en la medida en que la forma de vida de estos sujetos indeseables no sólo no se adecua a los estándares convencionales ${ }^{64}$, sino que además, los cuestiona de forma directa por no someterse a ellos. Dicho de otro modo, la pobreza conformaba una deformación del cuerpo social que confrontaba el adecuado devenir colectivo ${ }^{65}$ y por lo tanto, todas estas personas conformaban una población ociosa, beligerante, criminógena y poco útil a los objetivos del nuevo orden social. Así las cosas, tal es la preocupación que suscitaba la compresión de los fenómenos sociales surgidos desde y entorno a la pobreza que hasta se puede hablar de una suerte de disciplina social denominada pauperismo ${ }^{66}$ que tiene su razón de ser en el estudio y comprensión de todas aquellas formas de vida antinaturales que surgen alrededor de la pobreza ${ }^{67}$.

57 VON BAR (1916), 110-111.

58 Rusche Y KIRCHHEIMER (2004), 19 y ss.

59 CASTEL (2009), 97 y ss. Sobre las diferencias/similitudes conceptuales entre las nociones de pobre, mendigo y vagabundo, MAZA ZorRILla (1987), 15 y ss.

60 Garland (1990), 97 y ss.; Rusche Y KiRCHHEIMER (2004), 19-20.

61 Rusche Y KIRCHHEIMER (2004), 24.

62 DobB (1988), 266 y ss.; GutTon (1974), 11 y ss.

63 Procacci (1990), 158.

64 GutTon (1974), 11 y ss.; Procacci (1990), 161 y ss.

65 Procacci (1990), 158-159.

66 Sobre el concepto de Pauperismo, in extenso Breman (2016).

67 En relación con esta definición, es preciso matizar que la concepción del pauperismo como una suerte de disciplina social de estudio resulta una idea fundamentalmente desarrollada por Giovanna Procacci, Procacci (1990), 153 y ss. La conversión del pobre en un objeto de estudio posee múltiples implicaciones entre las que destacar el interés por distinguir entre los sujetos verdaderamente merecedores de asistencia social y los usurpa- 
Sentado lo anterior, y retomando el estudio de la delincuencia patrimonial fúnebre desde la economía política de la pena, es preciso reiterar que los postulados de esta racionalidad punitiva no se pueden comprender desligados de las condiciones estructurales de la sociedad capitalis$\mathrm{ta}^{68}$. En este sentido, la labor que las instituciones penales despliegan sobre el cuerpo social responden a intereses económicos que pueden reconducirse a un doble objetivo: sensibilizar a la sociedad de que formar parte de la estructura social es siempre más ventajoso que optar por la vía de la criminalidad y disciplinar a la población para que engrosen las filas de la creciente fuerza de trabajo capitalista ${ }^{69}$. Dicho de otro modo, los poderes públicos ponen en marcha todo un conjunto de políticas, en este caso disciplinarias, que tienen por objetivo proletarizar a todas aquellas personas a las que las redes tejidas por el capitalismo todavía no habían podido acceder. En línea con lo anterior, y como forma de perseverar en la implementación de estas voluntades político-criminales, se arbitra como solución la detención y confinamiento obligatorio de sujetos indeseables (ladrones, vagos, mendigos, prostitutas) en lugares que eviten sus nocivos estilos de vida y donde se les conmine a incorporar los valores, usos y costumbres precisos para poder vivir adecuadamente en sociedad $^{70}$. De este modo, surgen en Europa toda una pléyade de instituciones como las Workhouses en Inglaterra, los Hopitaux Generaux en Francia o las Rasphuis y Spinhuis en Países Bajos ${ }^{71}$. Las premisas con base en las que se justificaron la creación de estas instituciones recién señaladas también sirven para justificar, al menos en parte, el nacimiento de la prisión, pues el origen de los dispositivos penitenciarios tal como los concebimos actualmente "se ubica en la transición desde un régimen punitivo orientado a la destrucción del cuerpo (...) hacia otra lógica de castigo encaminada a la preservación del cuerpo, en la medida en que este puede ser explotado en los procesos capitalistas de producción ${ }^{72}$. Así las cosas, la prisión disciplina cuerpos y moldea voluntades con el fin de integrarlas en la dinámica de producción capitalista. En definitiva, es en este sentido de conversión y cambio en el que hay que entender la relación entre

dores que se aprovechan de ella pero no son justos destinatarios (DonZelot (2007), 71-72; MaZa ZorRilla (1987), 46-47; Mollat (1978), 303 y ss.). En este contexto, la moralidad se convierte en un criterio rector con base en el que clasificar grupos poblacionales. Asimismo, este merecimiento, adquiere un valor intersubjetivo como criterio próximo al orden y capaz de normar los comportamientos colectivos (Donzelot (2007), 71; Procacci (1990), 157-158).

68 Rusche Y Kirchheimer (2004), 27 y ss. En un sentido crítico sobre esta última cuestión, GARLAND (1990), 105 y ss.

69 Brandariz García (2019), 28-29; Garland (1990) 95; LEA (2006), 87-88.

70 Sobre el asentamiento de este tipo de modelos de vida en las comunidades de clase obrera, LEA (2006), 108 y ss.

71 Anitua (2005), 63 y ss.; Melossi Y Pavarini (1980), 29 y ss. Sobre estas cuestiones pero tomando como marco de estudio, los espacios penitenciarios en Valencia, SERNA ALONSO (1988), 69 y ss.

72 De Giorgi (2006), 7. 
cárcel y fábrica, pues conforma una «mutación antropológica» que para MELOSSI y PAVARINI resulta la «verdadera invención penitenciaria ${ }^{73}$ ».

Llegados a este punto, y tras la incorporación de los excursos anteriores, es preciso recuperar la idea de que la represión de la delincuencia patrimonial se erigió desde la Edad Media como un desasosiego central para las clases dirigentes ${ }^{74}$. Esto no cambió con el advenimiento de la modernidad, ya que para el orden social burgués el concepto de propiedad privada siguió ocupando un espacio protagónico. En consecuencia, la represión patrimonial se mantiene como una preocupación primordial ${ }^{75}$. En línea con esto, se establece una suerte de clase social, los no propietarios, considerada como tendencialmente equiparable a la de los criminales, y viceversa. En este contexto, la prisión, en tanto que herramienta al servicio del orden social burgués, estaba llamada a proteger al universo de los propietarios de los potenciales ataques producidos por los no propietarios. Para ello, no sólo debería contener físicamente a los sujetos infractores, sino que también debería (re)educarlos y convertirlos en sujetos socialmente inocuos. Es decir, no propietarios que acepten y reproduzcan el statu quo sin amenazar la propiedad ${ }^{76}$.

Lo recién expuesto se trae a colación aquí como forma de explicar, al menos en parte, las razones del legislador penal para la tipificación de los actos indebidos para con los difuntos y su memoria. En este sentido, la preocupación decimonónica por defender los derechos patrimoniales resultaba algo de tanta importancia que su esfera de control se expandía hasta los actos realizados contra los difuntos. En consecuencia, y con base en este criterio, se consideran merecedores de castigo todos los actos que atentasen contra los bienes que acompañen un cadáver, ya fuese de forma ornamental, ritual o del tipo que sea. En este sentido, los ilícitos contra el respeto debido a los difuntos adquieren un carácter que se desliza hacia consideraciones de naturaleza esencialmente materialista, ya que se vincula el respeto a los difuntos con la incolumidad de los elementos físicos que lo acompañan. Sin embargo, y tal como se señala a lo largo de todo este apartado, esta tendencia político-criminal no puede entenderse despegada de un contexto donde el asentamiento del capitalismo marca, indefectiblemente, la trascendencia social de las lesiones contra el patrimonio. Por todo ello, la defensa a ultranza de la propiedad en un tipo penal, aparentemente tan alieno, como el delito de violación de los enterramientos, ejerce como símbolo de condensación ${ }^{77}$ de una

73 Melossi Y PaVARini (1980), 190.

74 Rusche Y KiRCHHEIMER (2004), 20.

75 Melossi Y PaVARINI (1980), 194.

76 Melossi Y PaVARINI (1980), 194-195.

77 Sobre el uso y explicación del término símbolo de condensación, LOADER, GIRLING Y SPARKS, 2000, 66. 
época en la que la represión de la delincuencia patrimonial se entendía como una prioridad fundamental del sistema penal.

\subsection{Higienismo y Medicina Social como reguladores de un nuevo orden urbano}

Hasta la segunda mitad del siglo XVIII el crecimiento de las ciudades no era concebido como un inconveniente. Es más, este problema no podía ser enunciado como tal, en la medida en que ni el propio escenario urbano se pensaba en estos términos. Es decir, no existía una preocupación por el crecimiento de las ciudades, porque estas no se pensaban en clave de trama urbana, sino más bien como una «multiplicidad enmarañada de territorios heterogéneos y poderes rivales ${ }^{78}$ ".

Con el advenimiento de la industrialización y el asentamiento del capitalismo, la ciudad tuvo que incorporar a su histórica configuración de espacio para el intercambio y el mercado una nueva función: servir como lugar de producción ${ }^{79}$. Esto generó una explosión demográfica que modificó el contexto urbano de manera inapelable ${ }^{80}$ y que tuvo su incidencia en una población que sufrió grandes modificaciones en su cotidianeidad; no sólo por razón del cambio escala de sus ciudades, sino por la irrupción de grandes transformaciones de naturaleza socioeconómica y política ${ }^{81}$.

A propósito de lo anterior, es preciso señalar que las ciudades no eran espacios habitados y organizados desde el consenso, sino que en ellas se manifestaba, de un modo palmario, la desigualdad y la injusticia social ${ }^{82}$. Buen ejemplo de ello lo conformaban los denominados «barrios malos ${ }^{83}$ » habitados mayoritariamente por proletarios y donde las condiciones de vida se desarrollaban en condiciones paupérrimas ${ }^{84}$. De hecho, así lo narraba Friedrich Engels cuando describía la situación que se encontraba en las calles de barrios como el de St. Giles (Londres) en 1845: «Las calles sirven de mercado: cestas de legumbres y de frutas, naturalmente todas de mala calidad y apenas comestibles, dificultan mucho más el tránsito, y de ellas emana, como de las carnicerías, un olor nauseabundo. Las casas están

78 Foucault (2009), 371. En este mismo sentido, Sennett (1978), 169 y ss.

79 Harvey (2008), 197 y ss. Rusche Y KirchHeimer (2004), 27 y ss.

80 Sobre el proceso de expansion urbana que se produjo en Europa desde el siglo XVIII, BaIroch Et AL. (1988). Sobre la expansión urbana experimentada en España, Palomero Gonzalez Y Alvariño Serra (2016), 45-46.

81 Como crítica contemporánea a la aparición de todos estos procesos de cambio urbano, ENGELS (1976).

82 HARVEY (2008), 49 y ss.

83 EngELS (2013), 1.

84 Ferguson (2011), 59 y ss.; Morley (2007), 66-67. 
habitadas desde el sótano hasta el techo, tan sucias en el exterior como en interior, y tienen un aspecto tal que nadie tendría deseos de vivir en ellas. Pero eso no es nada comparado con los alojamientos en los patios y las callejuelas transversales a donde; se llega por pasajes cubiertos, y donde la inmundicia y el deterioro por vejez exceden la imaginación. No se ve, por decirlo así, un solo vidrio intacto, los muros están destrozados, las guarniciones de las puertas y los marcos de las ventanas están rotos o desempotrados, las puertas -si hay-hechas de viejas planchas clavadas juntas; aquí, incluso en este barrio de ladrones las puertas son inútiles porque no hay nada que robar. Por todas partes los montones de detritos y de cenizas y las aguas usadas vertidas delante de las puertas terminan por formar charcas nauseabundas ${ }^{85}$..

A resultas de todos estos procesos, la imagen pública de las ciudades empezó a deteriorarse al tiempo que aumentaba su consideración de espacio patógeno del que brotaban focos de contaminación y transmisión de enfermedades ${ }^{86}$. No en vano, todas estas preocupaciones discurrían de forma paralela a la aparición de enfermedades que, como el cólera ${ }^{87}$, se propagaron de forma pandémica durante el siglo XVIII y XIX.

Fruto de lo anterior, y como parte del estudio que originaron todas estas epidemias, se generó un extenso corpus teórico ${ }^{88}$ del que resulta especialmente reseñable la doctrina miasmática ${ }^{89}$. De acuerdo con esta teoría, la destilación química, fermentación y putrefacción de aguas pantanosas y estancadas, cadáveres o emanaciones de enfermos generaban unos efluvios volátiles que, trasladados por vía aérea y acuática, se convertían en agentes patógenos transmisores de enfermedades (miasmas) ${ }^{90}$. Este tipo de agentes destilaban, en la mayoría de los casos, un olor/hedor

85 ENGels (2013), 3.

86 Morley (2007), 65. En relación con esto, resulta muy ilustrativo señalar que la esperanza de vida de una persona de clase trabajadora nacida en Bolton o Leeds entre 1831 y 1844 se situaba en los 18 años. Ringen (1979), 114. En relación con la esperanza de vida urbana en la Inglaterra del XIX, pero desde un plano más amplio, SzRETER (2003), 424-425.

87 El estudio del cólera resulta especialmente interesante, pues habida cuenta de su virulencia y mortandad, esta enfermedad se convirtió en objeto de atención y estudio prioritario durante el siglo XVIII. Dada la inabarcable bibliografía sobre el tema en este texto se recomiendan, sin ánimo de exhaustividad, las siguientes obras sobre el tema. CAVOOD Y Upton, (2013), 1106 y ss.; Martin (2019), 33 y ss.; Rodriguez Ocaña (1980), 252 y ss.; TORRECILLA, (1833).

88 En este punto, cabe señalar que 1845 y 1856 se publicaron en Inglaterra más de 700 obras relacionadas de algún modo con el cólera (RAmos Gorostiza (2014), 15).

89 La teoría miasmática se encontraba presente en los desarrollos médicos realizados en la época helénica (LAIN ENTRIALgo (1943), 45 y ss.; LARREA KILLINGER, (1997), 101 y ss.). De hecho, de un modo más concreto, esta teoría se encontraba documentada en el Tratado Hipocrático de los vientos (LARrea Killinger, (1997), 102). No obstante, durante el siglo XVIII, esta teoría ya no se enunciaba en los mismos términos, sino que se actualizó de acuerdo a los avances científicos (médicos y sobre todo químicos) del momento. CAPONI (2002), 161 y ss.; CORBIN, (1986), 13 y ss.; URTEAGA (1980), 4-5.

90 Giménez LóPEz (1999), 122 y ss.; GRANJEL Y CARRERAS PANCHÓN (2004), 72-76; URTEAGA (1980), 4. 
que los hacía perceptibles, de tal forma que «en la práctica, el olfato se convierte en el instrumento-centinela que advierte al médico de la presencia de la enfermedad ${ }^{91} »$. Así las cosas, la importancia de este sentido permitió la creación de una suerte de "lenguaje olfativo ${ }^{92}$ » a través del que codificar a los miasmas como un problema social ${ }^{93}$ que impidiese no sólo su producción, sino también su propagación ${ }^{94}$.

La situación urbana recién expuesta propiciaba un ambiente de malestar generalizado que brotaba con más intensidad entre la población que más sufría los rigores de la vida en la ciudad ${ }^{95}$. De hecho, esta precariedad cronificada exacerbaba la creación de ciclos de protesta ignotos en las urbes ${ }^{96}$ y tan sólo concebidos como inherentes al campesinado ${ }^{97}$. Así pues, la confluencia de insalubridad y violencia político-social generaba entre las clases dirigentes una concepción muy negativa del espacio urbano $^{98}$. De hecho, tanto es así que ese componente peyorativo alcanza, incluso, tintes de temor ${ }^{99}$. Es decir, el espacio urbano se percibe desde una doble vía: como nocivo para la salud y como espacio de conflicto y peligro para las estructuras de poder ${ }^{100}$. En este sentido, y como forma de ejemplificar esto, FOUCAULT acude a un sermón del abate Le Dreuille pronunciado en $1840 \mathrm{y}$ en el que este se ahonda en esta inquietud/temor de las clases pudientes: "Allí [entre los obreros], las necesidades son innumerables y los proyectos, más numerosos aún que las necesidades; los sueños de organización se discuten en la confusión y se preparan venganzas en las tinieblas. (...) Mas sabedlo, pues: comienzan a cansarse de esperar, y de no tomar precauciones, (...) aparecerá [el pueblo] como el ángel exterminador en medio de vuestros ricos hoteles y vuestras suntuosas moradas ${ }^{101}{ }$.

91 Larrea Killinger (1997), 201. En este mismo sentido, Ferreiro Ardións (2012), 49.

92 GRANJEL Y CARRERAS PANCHÓN (2004), 78.

93 Foucault (2009), 376-377. Giménez López (1999), 124 y ss. Sobre el control específico de los flujos de aire y agua en la Barcelona, Madrid y Valencia del siglo XIX, JORI (2013), 11 y ss.; PAlomero GonZÁlez Y AlVARiÑo Sierra (2016), 45 y ss.

94 LARREA Killinger (1997), 155 y ss.

95 Sobre esta cuestión, y con base en el ejemplo específico de la ciudad de Paris, Richard Sennett ejemplifica esta cuestión en los siguientes términos: "Para imaginar la experiencia del crecimiento demográfico dentro de París en la primera mitad del siglo XIX, se debería pensar» en una caja llena de trozos de cristal; cuanto más cristal se introduzca dentro de la caja, los trozos de cristal se romperán bajo la presión, aunque los laterales de la caja los contengan» SENNETT (1978), 169.

96 En relación con estos ciclos de protestas en el Paris de 1830-1848, HaRVEy (2008), 79 y ss.

97 Diz Reboredo Y Fernández De Rota Irima (2017), 10; Foucault (2009), 372.

98 A sensu contrario, durante este período se comienza a desarrollar una concepción de la vida en el campo bucólica y desprovista de todas las externalidades asociadas a la vida en la ciudad. Así pues, se construye una perspectiva idealizada del entorno rural que se plantea como alternativa (política, sanitaria, estética) al incipiente mundo urbano. HARVEY (2008) 36 y ss.

99 Diz Reboredo Y Fernández De Rota Irima (2017), 10; Foucault (2009), 372.

100 Ramos Gorostiza (2014), 20; Ringen (1979), 118; STOTT Y DRURY (2017), 4 y 5.

101 Foucault (2018), 190. 
Así pues, se desarrolla una atmósfera de «miedo-ambiente ${ }^{102}$ » que debe ser entendida como «el producto histórico generado por el acondicionamiento material y discursivo del espacio urbano. Un producto con su propia historia. No un universal, sino una sustancia propia de la modernidad ${ }^{103}$ ». En consecuencia, las clases poderosas consideran urgente diseñar nuevos modelos de ciudad a través de los que intentar paliar todas estas externalidades ${ }^{104}$. De esta forma, se diseña un nuevo orden urbano ${ }^{105}$ cuya gestión se encuentra fuertemente delimitada por discursos de naturaleza higienista, en su acepción más próxima al concepto británico ${ }^{106}$, y de medicina urbana, entendida de acuerdo a los estándares franceses ${ }^{107}$. En este sentido, son múltiples las intervenciones llevadas a cabo con la intención de acomodar la trama urbana a los postulados recién expuestos ${ }^{108}$. En este texto, y por razón de concreción, interesan más las reformas que tuvieron que ver el respeto debido a los difuntos, lo que lleva a un análisis un poco más pormenorizado de la configuración y gestión que se realizó durante este período de los cementerios y lugares de enterramiento.

Los cementerios, por su propia condición de lugares en los que reposan los cuerpos de las personas fallecidas, resultaban un problema

102 In extenso sobre la expresión «miedo-ambiente» (ambient fear) DoEL y CLARKE (1997).

103 Diz Reboredo Y Fernández De Rota Irima (2017), 8.

104 SENNETT (1978), 169-174.

105 JoRi (2013), 1; GIMÉNEZ LÓPEZ (1999), 127 y ss. En este sentido, y viendo el orden urbano desde un punto de vista estrictamente arquitectónico, resulta interesante este artículo López Díaz sobre los orígenes de la vivienda social, LóPEz DíAz, (2003), 161 y ss.

106 El higienismo, en sus primeras enunciaciones, debe entenderse muy vinculado al Sanitiry Movement británico surgido durante la primera mitad del siglo XIX. A través de su principal impulsor, Edwin Chadwick, se llevaron a cabo todo un conjunto de medidas (modificación del ambiente físico urbano, la salubridad de las ciudades y la mejora de las condiciones de vida de la población, con especial atención a las clases trabajadoras) que intentasen paliar los nocivos efectos del proceso industrializador. Sobre el movimiento higienista, sin ánimo de exhaustividad, JENSON (2008); MoRley (2007), 67 Y Ss.; RAMOs GoRostiza (2014), Ringen (1979); STRAND (2019), 411 y ss.,

107 La aproximación al concepto de medicina urbana se realiza en texto de acuerdo con los postulados Foucaultianos (Foucault (2009), 362 y ss.). Así pues, la medicina urbana, junto con la medicina de estado y medicina de la fuerza laboral, conforma la denominada medicina social. La medicina urbana surgió en la segunda mitad del Siglo XVIII como una consecuencia del proceso de urbanización y perseguía tres objetivos principales: 1. Analizar los lugares de acumulación o hacinamiento que pudieren generar problemas de salud pública. 2. Controlar el flujo de los elementos, esencialmente aire y agua, para evitar la producción y propagación de agentes patógenos. 3. Organizar los elementos sanitarios necesarios (fuentes, desagües, lavaderos) para el buen desarrollo de la vida en común.

108 En relación con esta cuestión, sirve como ejemplo paradigmático la remodelación urbana planificada por Haussman para la ciudad de Paris. Dentro de su reforma se incluían cuestiones tan variadas como: la apertura de calles y avenidas, la reorganización barrial de la ciudad en atención a criterios socioeconómicos, la sanitarización de la ciudad o la construcción de un medio urbano refractario a la movilización y protesta popular. En relación con esta cuestión y desde diversas ópticas LAURIAN (2019), 296 y ss.; Marcus (2001); PAccoud (2019); SenNetT, (1978), 169 y ss. 
urbano de primer orden, ya que las condiciones de (in)salubridad que acompañaban a estos lugares eran el origen de múltiples problemas. Esto propicia la búsqueda de soluciones que confluyan en torno a la idea de ubicar estos equipamientos lejos de los centros urbanos ${ }^{109}$.

De una manera incipiente, y como primer escollo, estas propuestas alternativas encontraban resistencias en la tradición altomedieval de inhumar los cadáveres dentro de las iglesias ${ }^{110}$. En relación con esto, y de manera complementaria, otro inconveniente lo conformaba la importancia económica de los enterramientos dentro de los templos. Así pues, la sepultura dentro de una iglesia estaba acompañada del pago de un canon que suponía una importante fuente de ingresos para muchas diócesis y congregaciones religiosas $^{111}$ que veían con reticencias perder esa fuente de ingresos ${ }^{112}$.

De todos modos, todas las resistencias al traslado de los cuerpos a los cementerios a las que se acaba de hacer referencia pronto se vieron superadas por el propio devenir de los acontecimientos. En este sentido, puede servir como ejemplo la situación del cementerio de los Santos Inocentes ${ }^{113}$ en París durante el siglo XVIII ${ }^{114}$. Más en concreto, el crecimiento demográfico de la capital francesa hizo que en este cementerio se sepultasen hasta su cierre en 1780 entre 2000 y 3000 personas al año. Esto implicaba una densidad poblacional de 300 cadáveres por metro cuadrado ${ }^{115}$ y una elevación de la cota del cementerio de más de 2 metros respecto de sus calles colindantes ${ }^{116}$. Este hecho, unido a las precarias condiciones

109 Foucault (2009), 375; Groizard Y Gomez De La Serna (1870), 11.

110 A fin de contextualizar esta cuestión y como apunte histórico es preciso señalar que los ritos funerarios alto medievales no se correspondían con los celebrados en la antigüedad. Los primeros cristianos, en seguimiento de las prácticas romanas (GARRIDO JiMÉNEZ (2014), 914), daban sepultura a sus cadáveres en lugares distintos a sus viviendas o templos (EsPINAR MoReno (2002), 74-75). Esta tradición encontró un punto de ruptura en el siglo IV cuando la Iglesia, en agradecimiento por los servicios prestados al Cristianismo, permitió que los restos del Emperador Constantino se enterrasen en la Basílica de los Santos Apóstoles (Constantinopla) (EsPinar Moreno (2002), 76; Groizard Y Gomez DE LA SERNA (1870), 12-13; JoRI (2013) 3). Con el paso del tiempo, este criterio excepcional se hizo extensivo a religiosos de alto rango, reyes y demás personalidades (ESPINAR MORENO (2002), 76-77) de tal forma que la inhumación dentro de un templo religioso pasó a considerarse como una señal de estatus social (Giménez López (1999), 137; SATONJA (1999). Esto propició que esta ceremonia funeraria, otrora exclusiva, se popularizase y se convirtiera en un rito cada vez más solicitado.

111 Giménez López (1999), 137; MARTínez De Sánchez, (2005), 120-123; Scholz (2017), 447 Y SS.

112 Carreras Panchon Y Granjel (2005), 607 y ss.; Scholz (2017), 447 y ss.

113 LAQueur (2015), 218. .El cementerio de los Santos Inocentes se ubicaba bajo la actual Plaza Joachim-du-Bellay dentro del distrito 1 y muy próxima al antiguo mercado de Les Halles.

114 Foucault (2009), 373; Schriver Y Martínez CaVero (2012), 11.

115 LAQUEUR (2015), 225.

116 Esta elevación de la cota dentro del cementerio se producía por razón de que el método de inhumación realizado residía en disponer los cadáveres de manera superpuesta unos encimas de otros. De esta forma, y por razón del elevado número de cuerpos 
en las que se realizaban las inhumaciones y los cuidados que recibían las sepulturas ${ }^{117}$, evidenciaba de forma palmaria los riesgos sanitarios inherentes a la convivencia con tal cantidad de cadáveres. En consecuencia, el traslado de los cementerios a la periferia dejó de ser un problema para convertirse en una prioridad de máxima urgencia. Por todo ello, los poderes públicos, ahora con el apoyo de los estamentos clericales, pugnaron de manera intensa por la reubicación de los cementerios en espacios alejados de los centros urbanos ${ }^{118}$.

En resumen, y como forma de compendiar lo recién expuesto, se podrían citar cuatro razones a través de las que comprender la perentoria necesidad de trasladar las sepulturas lejos de las ciudades ${ }^{119}$ : En primer lugar, la existencia de peligros sanitarios que se derivan de las exhalaciones y descomposiciones cadavéricas alojadas en las iglesias. En segundo lugar, la fuerza ejercida por el clero pues, por razón de su proximidad con las sepulturas, conformaban el grupo poblacional de mayor riesgo. En tercer lugar, la recuperación de la ortodoxia cristiana previa al medievo que aprobaba la realización de enterramientos en ubicaciones fuera de las iglesias. En cuarto lugar, la victoria del pensamiento iluminista que anteponía el raciocinio a los usos y costumbres provenientes del prejuicio y la superstición y que permitió a FOUCAULT construir la siguiente reflexión: "la individualización del cadáver, del ataúd y de la tumba aparecieron a fines del siglo XVIII por razones no teológico-religiosas de respeto al cadáver sino por motivos de político-sanitarios de respeto a los vivos. Para proteger a los vivos contra la influencia nefasta de los muertos, es preciso que estos últimos estén tan bien clasificados - o mejor posible -que los primeros ${ }^{120}$ ».

Por todo ello, y sentado lo anterior, es posible sostener la existencia de un fuerte vínculo entre la preocupación penal por la realización de conductas indebidas para con los difuntos y la inquietud suscitada por la necesidad de gestionar nuevos y múltiples problemas relacionados con la muerte. Así pues, la inusitada expansión demográfica experimentada por las ciudades europeas durante los siglos XVIII-XIX provocó la aparición de situaciones desconocidas para las que no existían soluciones convincentes. En este contexto, las consideraciones político-sanitarias emergen como una cuestión central.

Más en concreto y vinculados con el objeto de estudio de este texto, los problemas de salubridad aparejados al deficiente tratamiento de lo

\footnotetext{
enterrados en este cementerio, se producía la elevación del terreno arriba descrito. Sobre esto, Laqueur (2015), 218. Schriver Y Martínez CaVero (2012), 11.

117 Granjel Y Carreras Panchon (2004), 77; JORI (2013), 3.

118 Espinar MoReno, (2002), 77 y ss.

119 Calatrava (1991), 349 y ss.; Espinar Moreno (2002); Giménez López (1999), 137 y ss.; Granjel Y Carreras Panchon (2004), 78-79; Satonja (1999); Schriver Y Martínez CAVERo (2012), 11 y ss.

120 Foucault (2009), 375-376.
} 
mortuorio ocasionaban gravísimas consecuencias. La manipulación no autorizada de cadáveres aumentaba, hasta niveles intolerables, el riesgo de propagar y contraer diversos tipos de enfermedades. En este sentido, y desde un punto de vista estrictamente político-criminal la búsqueda de respuestas desarrolló todo una serie de lógicas represivas que tenían su centro de atención en las conductas indebidas para con los difuntos. Desde esta perspectiva, resulta coherente el castigo de todos aquellos actos que se lleven a cabo sobre los cadáveres, puesto que aumentan los riesgos de contracción y contagio de enfermedades ${ }^{121}$. Por todo ello, y en aplicación del Ius Puniendi, los agentes político-criminales decimonónicos consideran que la represión de estas conductas no sólo era legítima, sino que era indispensable para atajar este complejo problema social.

\section{Recapitulación conclusiva}

Con la realización del trabajo expuesto en los apartados anteriores se intenta efectuar un acercamiento histórico, genealógico y contextualizado a unos tipos que nunca han suscitado gran interés a nivel doctrinal a pesar de que resulten los testigos directos de toda una lógica punitiva que, si bien periférica, gozó de amplio desarrollo a lo largo del siglo XIX. De hecho, y tal como se expone supra, el Legislador penal estimó oportuno incorporar en todos los Códigos Penales del siglo XIX delitos enfocados al castigo de actos indebidos para con los difuntos y su memoria.

Así las cosas, la existencia de esta pertinaz querencia del Legislador decimonónico por la represión de estos delitos se asienta en la base de una tendencia punitiva que, sin duda, responde a intereses políticocriminales de muy diversa índole. En este sentido, uno de los objetivos principales de este trabajo reside en el estudio de estas razones y en la influencia que, eventualmente, pudieron tener en la configuración de estos tipos.

Más allá de las pretensiones recién expuestas, con la realización de un trabajo de estas características también se pretende realizar un acercamiento a muchos de los puntos neurálgicos entorno a los que se estructuraba la sociedad española del siglo XIX. Dicho de otro modo, los delitos contra los actos indebidos para con los difuntos y su memoria muestran a través de su configuración y estructura muchas de las preocupaciones, intereses y tensiones de su época. En este sentido, su disección permite poner de manifiesto cuestiones tan diversas como: a) La fortísima influencia de la religión católica en la configuración de la política criminal. b) La total vigencia de lógicas represivas que tienen como por objetivo la consolidación del capitalismo como sistema económico-

121 Groizard Y Gomez De La SERna (1870), 13. 
social hegemónico. c) La existencia de enérgicas resistencias al asentamiento de proyectos de naturaleza iluminista que no gozasen del beneplácito, explícito o tácito, de los principales grupos de poder en aquel momento vigentes. d) La utilización del Derecho Penal como herramienta de control vinculada a disciplinas tan aparentemente alienas como la Salud Pública. En este sentido, el estudio histórico de estos ilícitos no sólo permite conocer de una manera pormenorizada las características de una determinada familia delictiva, sino que también revela consideraciones generales a partir de las que realizar mejores aproximaciones al contexto político-criminal general imperante en aquel momento.

Sentado lo anterior, la función de este trabajo no se agota en el conocimiento contextualizado de estos delitos. Así pues, los actos que atenten contra el respeto debido a los difuntos siguen conformado en la actualidad una conducta penalmente relevante (artículo $526 \mathrm{CP}^{122}$ ). En este sentido, y más allá de que este trabajo se centre en el análisis de cuestiones de carácter histórico y por lo tanto escrutar las razones político-criminales actuales subyacentes al vigente artículo $526 \mathrm{CP}$, esto no supone que sus argumentos resulten totalmente estériles en análisis presentes. La contraposición de la realidad decimonónica con la actual puede mostrar pautas normativas, interpretaciones conceptuales o puntos de vista analíticos que tanto por similitud como por divergencia enriquezcan un potencial estudio de los delitos contra el respeto debido a los difuntos. En este sentido, y de una forma metafórica, este trabajo no pretende ser tan solo un espejo en el que se reflejen los tipos vigentes, sino también una herramienta que contribuya a la mejora de los estudios penales contemporáneos.

\section{Bibliografía}

Abel, Francisco (1983): «El morir cristiano», en: Iglesia Viva. Revista de Pensamiento Cristiano, ( $n^{\circ} 183$ ), pp. 543-569.

Agamben, Giorgio (2006): El tiempo que resta. Comentario a la Carta a los Romanos, (Madrid, Trotta).

Anitua, Gabriel Ignacio (2005): Historias de los pensamientos criminológicos, (Buenos Aires, Ediciones del puerto).

AnTón OnecA, José (1965): «Historia del Código penal de 1822», en: Anuario de Derecho Penal y Ciencias Penales, (Tomo 18, Mes 2), pp. 263-278.

122 Artículo 526 CP 1995.

El que, faltando al respeto debido a la memoria de los muertos, violare los sepulcros o sepulturas, profanare un cadáver o sus cenizas o, con ánimo de ultraje, destruyere, alterare o dañare las urnas funerarias, panteones, lápidas o nichos será castigado con la pena de prisión de tres a cinco meses o multa de seis a 10 meses. 
Badiou, Alain (1999): San Pablo. La fundación del universalismo, (Barcelona, Anthropos).

Bairoch, Paul; BATOU, Jean y Chèvre, Pierre (1988): La population des villes européennes de 800 à 1850, (Gèneve, Droz).

BASTERRA PÉREZ, ÁNGEL (2006): La muerte a través del discurso del personal sanitario. El caso de las instituciones hospitalarias en Alicante, (Tesis Doctoral, Universidad de Alicante) http://rua.ua.es/dspace/ handle/10045/9562.

Brandariz García, José Ángel (2019): La Economía Política de la Pena, (Madrid, Iustel).

Calatrava, Juan Antonio (1991): «El debate sobre la ubicación de los cementerios en la España de las Luces: la contribución de Benito Bails», en: Espacio, tiempo y forma. Serie VII, Historia del arte, $\left(n^{\circ}\right.$ 4), pp. 349-366.

Catalá, Santiago (2018): «Factor religioso y Derecho penal en el Código de 1870», en: Martí Sánchez José María y Moreno Mozos María DeL MAR (CoORDs.): Derecho de difusión de mensajes y libertad religiosa, (Madrid, Dykinson), pp. 23-50.

CAPONI, SANDRA (2002): «Miasmas, microbios y conventillos», en: ASCEPLIO. Revista de la Historia de la Medicina y la Ciencia (Vol. $54 \mathrm{n}^{\circ}$ 1), pp. 155-182.

Carreras Panchón, José Luís y Granjel Mercedes, (2005): «Regalismo y policía sanitaria. El episcopado y la creación de cementerios en el reinado de Carlos III», en: Hispania sacra, (Vol. 57 n 116 ), pp. 589-624.

CASTEL, RoBERT (2009): La metamorfosis de la cuestión social: una crónica del asalariado, (Barcelona, Paidós).

De Castro Y Orozco, José Y Ortiz De Zuñiga, Manuel, (1848), Código penal explicado, para la común inteligencia y fácil aplicación de sus disposiciones, Volumen II (Granada, Imp. y Librería de Manuel Sanz).

CAvOOD, IAN Y Upton, CHRIs (2013): « «Divine Providence»: Birmingham and the Cholera Pandemic of 1832», en: Journal of Urban History, (Vol. 39 n6), pp. 1106-1124.

Corbin, Alain (1986): Le Miasme et la Jonquille: l'odorat et l'imaginaire social XVIIIe-XIXe siècles, (Paris, Flammarion).

Colomer Bea, David (2019): «El Dret penal i la identitat religiosa» en: Indret: Revista para el Análisis del Derecho, (nº 3), pp. 1-37.

Cuello Calón, Eugenio (1954): «La protección penal de la religión», en: Revista Española de Derecho Canónico, (Vol. 9 n² 27) pp. 923-929.

De Giorgi, Alessandro. (2006): Re-thinking the Political Economy of Punishment, (Aldershot, Ashgate). 
Del Hoyo, JAVIER (2017): "Ne velis violare. Imprecaciones contra los profanadores de tumbas», en: CAMPOS Y FERNÁNDEZ DE SEVILLA, Francisco Javier (coord.), El mundo de los difuntos: culto, cofradías y tradiciones, Vol. 2, (San Lorenzo del Escorial, Ediciones Escurialenses), pp. 809-824.

Diz Reboredo, Carlos Y Fernández De Rota Irima, Antón (2017): «Miedo-Ambiente: Del urbanismo disciplinario, la sociedad de control y sus indignados», en: Revista San Gregorio (n 17), pp. 6-15.

DobB, Maurice (1988): Estudios sobre el desarrollo del capitalismo, (Madrid, Siglo XXI editores).

Doel, Marcus A Y Clarke David B (1997): «Transpolitical Urbanism: Suburban Anomaly and Ambient Fear», en: Space and Culture, (Vol. $\left.1 \mathrm{n}^{\circ} 2\right)$, pp. 13-36.

Donzelot, Jacques (2007): La invención de lo social. Ensayos sobre la declinación de las pasiones políticas, (Buenos Aires, Nueva Visión).

ENGELS, FRIEDRICH (1976): La situación de la clase obrera en Inglaterra, (Madrid, Akal).

ENGELS, FRIEDRICH (2013): «Las grandes ciudades», en: Bifurcaciones: Revista de Estudios Culturales Urbanos, ( $\left.\mathrm{n}^{\circ} 12\right)$, pp. 1-13.

EsPinar Moreno, MANUel (2002): «Costumbres sobre las sepulturas cristianas en la Baja Antigüedad y de la Alta Edad Media», en: Estudios sobre patrimonio, cultura y ciencias medievales, (n 3-4), pp. 69-86.

Ferguson, Eliza (2011): «The Cosmos of the Paris Apartment: Working Class Family Life in the Nineteenth Century», en: Journal of Urban History, (Vol. $37 \mathrm{n}^{\circ} 1$ ), pp. 59-67.

Ferreiro ARdións, MANuel (2012): El cólera en las transformaciones del siglo XIX en Álava. La epidemia de 1834, (Álava, Tesis DoctoralUniversidad del País Vasco) (https://addi.ehu.es/handle/10810/10823)

Foucault, Michel (1994): Dits et Écrits (1954-1988), Vol. 3 (1976-1979), (Paris, Gallimard).

Foucault, Michel (2009): «Nacimiento de la Medicina Social», en FouCAULT, Michel: Estrategias de Poder. Obras Esenciales II, (Barcelona, Paidós), pp. 363-384.

Foucault, Michel (2018): La Sociedad Punitiva. Curso del Collège de France (1972-1973), (Madrid, Akal).

Galindo Hervás, Alfonso (2008): «Mesianismo impolítico», en: Isegoría. Revista de Filosofía Moral y Política (nº 39), pp. 239-250.

GARCÍA GARCÍA, RicARdo (1999): «El primer Código Penal español de 1822 y su regulación de la religión católica», en Derecho y opinión, $\mathrm{n}^{\mathrm{0}} 7$, pp. 343-364 
GARRIDO JimÉNEZ, MANUEL (2014): «Columbarios y urnas funerarias», en: Campos Y Fernández De Sevilla, Francisco Javier (CoOrd.) El mundo de los difuntos: culto, cofradías y tradiciones, Vol. 2, (San Lorenzo del Escorial, Ediciones Escurialenses), pp. 911-922.

Garland, David (1990): Punishment and Modern Society. A Study in Social Theory, (Oxford, Clarendon).

Gimenez LóPez, MANuEl (1999): «La exhalación de la muerte: la aportación del matemático Benito Bails a la polémica sobre los cementerios en el siglo XVIII», en: Revista de historia moderna: Anales de la Universidad de Alicante, ( $\left.n^{\circ} 17\right)$, pp. 113-146.

Granjel, Mercedes Y Carreras PANCHÓN, ANTONIO (2004): «Extremadura y el debate sobre la creación de cementerios: un problema de salud pública en la Ilustración», en: Norba: Revista de Historia, ( $\left.n^{\circ} 17\right)$, pp. 69-91.

Groizard Y Gomez De La Serna, Alejandro (1870), El Código Penal de 1870, Volumen IV, (Burgos, Timoteo Arnáiz).

GutTon, JEAN-PiERre, (1974): La société et les pauvres en Europe (XVIXVIII siècles), (Paris, Presses universitaires de France).

Harvey, David (2008): Paris, Capital de la Modernidad, (Madrid, Akal).

Hertz, Robert (1990): La muerte y la mano derecha, (Madrid, Alianza Universidad).

Jenson, Jane (2008): «Getting to Sewers and Sanitation: Doing Public Health within Nineteenth-Century Britain's Citizenship Regimes», en: Politics \& Society, (Vol. $\left.36 \mathrm{n}^{\circ} 4\right)$, pp. 532-566.

JORI, GERARD (2013): «La ciudad como objeto de intervención médica. El desarrollo de la medicina urbana en España durante el Siglo XVIII», en: Scripta Nova. Revista electrónica de geografía y ciencias sociales, (Vol. XVII, n 431), pp. 1-25.

Lafuente Benaches, María Mercedes (2016): Exhumaciones Jurídicas (Valencia, Tirant lo Blanch).

Lain Entrialgo, Pedro (1943): Estudios de Historia de la Medicina y de Antropología Médica, (Madrid, Ediciones Escorial).

Laqueur, Thomas W. (2015): The work of the dead. A cultural history of mortal remains, (Princeton, Princeton University Press).

LARREA KILlinger, CRISTINA (1997): La cultura de los olores: una aproximación a la antropología de los sentidos, (Quito, Abya-Yala).

LAURIAN, Lucie (2019): «Planning for Street Trees and Human-Nature Relations: Lessons from 600 Years of Street Tree Planting in Paris», en: Journal of Planning History, (Vol. $18 \mathrm{n}^{\circ} 4$ ), pp. 282-310.

LeA, John (2006): Delito y Modernidad. Nuevas argumentaciones en la criminología realista de izquierda, (México DF, Coyoacán). 
LiBANIO, JUAN BAUTISTA (1983): «La resurrección de los muertos», en: Iglesia Viva. Revista de Pensamiento Cristiano, (nº 183), pp. 571-590.

Llamas Vela, Antonio (2009): «Pablo, un rabino que explica a Jesús», en: Studia cordubensia: revista de teología y ciencias religiosas de los centros académicos de la Diócesis de Córdoba, (nº. 2), pp. 65-84.

LOADER, IAN; GIRLING, Evi Y SPARKs, Richard. (2000): «After success? Anxieties of affluence in an English village», en HOPE, TIM Y SPARKS, RICHARD. (eds.): Crime, Risk and Insecurity, (London, Routledge), pp. 65-82.

López Barja De Quiroga, Jacobo; Rodríguez Ramos, Luis Y Ruiz De GoRDEJUEla LóPez, Lourdes (1988): Códigos Penales Españoles, (Madrid, Akal).

LóPEZ DíAZ, JESús (2003): «La relevancia de la vivienda social en el origen de la arquitectura contemporánea», en: Espacio, Tiempo y Forma, Serie VII, Historia del Arte, (n $\left.{ }^{\circ} 16\right)$, pp. 179-197.

MANJón-CABEza Olmeda, Araceli (2013): «Constitución de 1812 y código penal de 1822 (algunas reflexiones sobre el tratamiento de la religión y la libertad ideológica y sobre la vigencia del texto penal)», en: Revista de Derecho Penal y Criminología, (no 9), pp. 143-172

MARcus, SHARon (2003): «Haussmannization as Anti-Modernity. The Apartment House in Parisian Urban Discourse, 1850-1880», en: Journal of Urban History, (Vol. $27 \mathrm{n}^{\circ}$ 6), pp. 723-745.

Martin, Myrna Gene (2019): «Outsiders on the inside: Italian Jewish Ghettos and Cholera in the 1830s», en: European History Quarterly, (Vol. $49 \mathrm{n}^{\circ} 1$ ), pp. 28-49.

MARTínez De SÁNCHEZ, ANA MaRÍA, (2005): « «La resurrección de los muertos»: significado del espacio sepulcral», en: Hispania Sacra, (Vol. 57, $\left.\mathrm{n}^{\mathrm{o}} 115\right)$, pp. 109-140.

MARX, Karl (1974): «Contribución A La Crítica De La Filosofía Del Derecho De Hegel», En: MARX, KARL Y EngELS, Friedrich, Sobre la Religión, (Salamanca, Sígueme).

Masferrer Domingo, ANiceto (2017) (Ed.): La codificación penal española tradición e influencias extranjeras: su contribución al proceso codificador (Cizur Menor, Thomson Reuters Aranzadi).

Maza Zorrilla, Elena (1987): Pobreza y Asistencia Social en España. Siglos XVI al XX, (Valladolid, Universidad de Valladolid).

Melossi, Dario Y Pavarini, Massimo, (1980), Cárcel y Fábrica. Los Orígenes del Sistema Penitenciario (siglos XVI-XIX), (Madrid, Siglo XXI Editores).

Melossi, Dario; Sozzo, Máximo Y Brandariz García, José Ángel (Eds.), (2018): The Political Economy of Punishment Today, (Abingdon, Routledge). 
Mollat, Michel (1978): Les pauvres au moyen age, (Paris, Hachette).

Morin, Edgar (1974): El hombre y la muerte, (Barcelona, Kairós).

Morley, IAN (2007): "City Chaos, Contagion, Chadwick and Social Justice», en: Yale Journal of Biology and Medicine, ( $\left.n^{\circ} 80\right)$, pp. 61-72.

Moro Abadía, Óscar (2006): «Presentismo»: Historia de un concepto», en: Cronos: Cuadernos valencianos de historia de la medicina y de la ciencia, Vol. 9, n 1 , pp.149-174.

NADEAU, JEAN GuY (2005): «El cristianismo nunca ha separado el alma del cuerpo», en: Selecciones de Teología, (n 174), pp. 155-160.

O’Callaghan, Paul (1989): «La fórmula «Resurrección de la carne» y su significado para la moral cristiana», en: Scripta Theologica: Revista de la Facultad de Teología de la Universidad de Navarra (Vol. 21, n ${ }^{\circ}$ 3), pp. 777-803.

Paccoud, Antoine (2019): «Badiou, Haussmann and Saint-Simon: Opening spaces for the state and planning between 'post-politics' and urban insurgencies», en: Planning Theory, (Vol. 18 n 3), pp. 339-358.

Pacheco, Joaquín Francisco (1870), El código penal comentado y concordado, Tomo II, (Madrid, Imp. de M. Tello).

Palomero González, José Antonio Y Alvariño Serra, Patricia (2016): «La importancia del Higienismo y la Potabilización del agua en la ciudad de Valencia (1860-1910)», en: Investigaciones Geográficas, $\left(n^{\circ} 65\right)$ p. 45-55.

Piñero SÁez, Antonio (2014): «El transfondo judío del binitarismo de Pablo de Tarso» en: Arys: Antigüedad: religiones y sociedades, $\left(\mathrm{n}^{\mathrm{o}}\right.$. 12), pp. 321-339.

Procacci, Giovanna (1991), «Social economy and the government of poverty», en Burchell, Graham, Gordon Colin Y Miller, Peter, (eds.), The Foucault Effect: Studies in governmentality, (Chicago, Chicago University Press).

Ramos Gorostiza, José Luís (2014): «Edwin Chadwick, el movimiento británico de salud pública y el higiniesmo español», en: Revista de Historia Industrial ( $\left.\mathrm{n}^{\circ} 55\right)$, pp. 11-38.

Ramos VÁzquez, José Antonio (2014): «El terreno de Dioniso: algunos apuntes sobre el concepto "persona» en el Derecho penal», en: Teoría y derecho: revista de pensamiento jurídico, ( $\left.\mathrm{n}^{\circ} .14\right)$, pp. 110-127.

RanciÈre, Jacoues (1996): El Desacuerdo. Política y Filosofía, (Buenos Aires, Nueva Visión).

RAtzinger, Joseph (2007): Jesús de Nazaret, (Madrid, Planeta).

RATZginger, Joseph (2016): Escatología: la muerte y la vida eterna, (Barcelona, Herder). 
RINGEN, KNut (1979): "Edwin Chadwick, the Market Ideology, and Sanitary Reform: On the Nature of the 19th-Century Public Health Movement», en: International Journal of Public Health, (Vol. $9 \mathrm{n}^{\circ} 1$ ), pp. 107-120.

RODRIGUEZ OCAÑa, ESTEBAN (1980): «Ciencia e ideología en torno a la primera epidemia de cólera en España: (1833-1835)», en GARMA Pons, SANTIAGo (coord.) El científico español ante su historia: la ciencia en España entre 1750-1850: I Congreso de la Sociedad Española de Historia de las Ciencias (Madrid, Diputación Provincial de Madrid), pp. 251-260.

Rusche, GEORGE Y KIRCHHEIMER, OTTO, (2009): Pena y Estructura Social, (Bogotá, Temis).

SATONJA, José Luís (1999), «La construcción de los cementerios extramuros: Un aspecto de la lucha contra la mortalidad en el antiguo régimen», en: Revista de Historia Moderna ( $n^{\circ} 17$ ), pp. 33-44.

Scholz, Maximilien (2017): «Over our dead bodies: The fight over Cementery Construction in Nineteenht-Century London», en: Journal of Urban History, (Vol. 43 n³), pp. 445-457.

Schriver, Klaus Y Martínez Cavero, Pedro (2012): «Reflexiones antropológicas sobre la historia y la actualidad del cementerio en Europa», en: Revista Murciana de Antropología, (n 19), pp. 9-26.

Segovia, Carlos A. (2013): «Pablo de Tarso, Israel y los gentiles. El nuevo enfoque radical sobre Pablo y el cariz judío de su mensaje» en: Bandue: revista de la Sociedad Española de Ciencias de las Religiones, $\left(\mathrm{n}^{\circ}\right.$ 7), pp. 181-205.

SEnNetT, Richard (1978): El declive del hombre público, (Barcelona, Península).

Serna Alonso, Justo (1988), Presos y Pobres en la España del XIX. La determinación social de la marginación, (Barcelona, Promociones y Publicaciones Universitarias).

Solano, Diego Andrés CRistancho (2014): «Resucitados resucitantes: la resurrección de los muertos en la actualidad», en: Reflexiones Teológicas ( $\left.\mathrm{n}^{\circ} 13\right)$, pp. 13-28.

Souto Galván, Esther (2016): «Tema 15. Tutela penal y gestión administrativa de la libertad religiosa» en SúAREz PERTIERRA, Gustavo et al., Derecho Eclesiástico del Estado, (Valencia, Tirant Lo Blanch), pp. 335-355.

StotT, ClifFord Y DruRY, John (2017): «Contemporary understanding of riots: Classical crowd psychology, ideology and the social identity approach», en: Public Understanding of Science (Vol. $26 \mathrm{n}^{\circ} 1$ ), pp. 2-14 
Strand, Michael (2019): «Public Health as a Matter of Concern: Victorian England, 1834-1848», en: Science, Technology, \& Human Values (Vol. 44 n$^{\circ} 3$ ), pp. 399-423.

SzReter, Simon (2003): «The Population Health Approach in Historical Perspective», en: American Jounal of Public Health, (Vol. 93 n³), pp. 421-431.

Tamarit Sumalla, Josep María (1989): La Libertad ideológica en el Derecho Penal, (Barcelona, Promociones y Publicaciones Universitarias).

TAubes, JACов (2007): La teología política de Pablo, (Madrid, Trotta).

Taubes, Jacob (2010): Escatología Occidental, (Buenos Aires, Miño y Dávila).

TERRADIllos Basoco, JuAn (2010): «Ideología y valores religiosos en el Código Penal. La reforma (siempre) pendiente», en: Laicidad y libertades: Escritos Jurídicos, (Vol. 10 n ${ }^{\circ}$ ), pp. 405-448.

TORRECILLA, Victoriano (1833): Historia de la epidemia del cólera morbo de París en 1832, y consideraciones generales sobre esta enfermedad, (Madrid, Ibarra).

Urteaga, Luis (1980): «Miseria, miasma y microbios. Las topografías médicas y el estudio del medio ambiente en el siglo XIX», en: Geo Crítica. Cuadernos críticos de Geografía Humana, (Año 5, no 29), pp. $1-34$.

Vilá Mayo, Juan Emilio (1983): «Los delitos contra la religión en el Derecho Penal Español», en: MiR PUIG, Santiago, Cordoba Roda, Juan y Quintero Olivares, Gonzalo (coords.) Estudios jurídicos en honor del profesor Octavio Pérez-Vitoria, Vol. 2, pp. 1065-1086.

Viviani, María Teresa (2007): «El cuerpo como santuario en los inicios del cristianismo», en: Aisthesis (n $\left.{ }^{\circ} 42\right)$, pp. 20-36.

Vizmanos, Tomás María Y Álvarez Martínez, Cirilo, (1848): Comentarios al Nuevo Código Penal, Tomo II, (Madrid, Estab. Tip. de J. González y A. Vicente).

Von Bar, CARL Ludwig (1916): A History of Continental Criminal Law, (Boston, Little, Brown, and Company).

ZAMORA, José ANTONIo (2010): «Mesianismo y escatología: la resurrección política de Pablo», en: Iglesia Viva. Revista de Pensamiento Cristiano, (n 241$),$ pp. 71-101.

ZizeK, Slavou (2005): El Títere y el Enano. El Núcleo Perverso del Cristianismo, (Barcelona, Paidós). 
